\title{
Tadeusz Lewowicki, Ewa Ogrodzka-Mazur, Barbara Chojnacka-Synaszko, Urszula Klajmon-Lech (eds.): Spheres of spiritual life - a study on permanence and changeability of identity behaviours in borderland communities.
} Munich 2018, LINCOM Academic Publishers, ss. $216^{1}$ (tłumaczenie na język angielski Agata Cienciała)

Znane zespoły badawcze akademickiego ośrodka Uniwersytetu Śląskiego w Cieszynie, a mianowicie nauczyciele akademiccy Zakładów: Pedagogiki Ogólnej i Metodologii Badań oraz Pedagogiki Społecznej i Edukacji Międzykulturowej, znani i mobilni autorzy kilkudziecięsiu książkowych prac zwartych oraz kilkuset artykułów, przygotowali tym razem do druku kolejne zbiorowe opracowanie w języku angielskim. Edytowane ono zostało na terenie Republiki Federacji Niemiec, co poza wiarygodnym jak zawsze walorem ogólnym opracowania tego Zespołu niewątpliwie powiększa jej poczytność na terenie państw UE. Książka ukazuje się w trudnym okresie redefiniowania przez uczelnie wyższe w kraju swojej tożsamości. Nastał czas - o dziwo?! - na ponownie sformułowane odpowiedzi na nieco banalne z pewnością uproszczone, a zarazem trywialne pytanie: Czy uczelnie są w ogóle komukolwiek potrzebne w dobie zmiany spotecznej, a jeśli tak, to jakim grupom osób, i jakie mają pozostawać podstawowe zadania - tak organiczne, jak i uzupetniające oraz w jaki sposób powinno się je obecnie realizować? Praca odegra niewątpliwie bardzo istotną rolę na międzynarodowym forum naukowym i to nie tylko z racji podejmowania stale aktualnej tematyki wielokulturowości, styczności oraz kontaktów i doświadczeń społeczności lokalnych pomimo reprezentowanych przez siebie odmienności. W obliczu fiaska wielu dotychczasowych zaleceń reprezentantów, a zarazem ekspertów w obszarze edukacji międzykulturowej, wnosi ona szereg nowych inicjatyw i propozycji

1 Tytuł w dowolnym tłumaczeniu na język polski brzmi następująco: Obszary życia duchowego. Studium o stałości i zmienności zachowań tożsamościowych spoteczności pogranicza. Książka, którą pozwalam sobie naszym Czytelnikom gorąco rekomendować, ukazała się w ramach serii Interculturalism and Intercultural Education (4). Redaktor serii: Hristo Kyuchukov, recenzenci wydawniczy: prof. prof. William New (USA), Andrzej Radziewicz-Winnicki (Polska). 
natury socjotechnicznej i socjalizacyjnej, przemawiających na rzecz integracji licznych społeczeństw Unii Europejskiej.

Członkowie Zespołu Autorskiego nie mają żadnych wątpliwości, że kreowanie określonych postaw wobec innej grupy, czy też porządkowanie świata w perspektywie stereotypowego dychotomicznego postrzegania w kategoriach: „swój” versus „obcy” dalekie pozostaje od pragmatycznej i scaleniowej wersji percepcji publicznej globalnego świata. Poprzez przekazanie Czytelnikom wielu szkiców i komunikatów z badań na terenie pogranicza polsko-czeskiego (w tym respondentów Czechów - uczniów ze szkół czeskich czy też uczniów narodowości polskiej (pochodzących także z rodzin mieszanych) zamieszkałych na terenie Republiki Czeskiej, uczęszczających do szkół z polskim językiem nauczania) już samo w sobie pozwala niweczyć nietolerancję czy też niechęć do tych, którzy nie są zaliczani do członków tzw. zbiorowości wtasnej (czyli swoich). Nie wprost poszczególni autorzy zajmują się kwestiami identyfikacji tożsamości narodowej, kreują oczekiwaną formę zachowań akceptowanych, jaką może przybierać sensownie prowadzony międzykulturowy dialog, który przezwycięża poczucie obcości, alienacji. Sygnalizowane są (bardziej lub mniej) widocznie inicjatywy wychodzące od samych społeczności lokalnych, które z pewnością przyczyniają się do ograniczenia jakichkolwiek uprzedzeń. Mniej widoczne, ale również ważne są poczynione niezliczone generalizacje. Mam na myśli starania Członków Zespołu Autorskiego na rzecz wiarygodnej i poprawnej relacji (wszelkich społeczności) pogranicza z reprezentantami egzystujących tam mniejszości etnicznych, wbrew jakiejkolwiek ksenofobii, uczulanie nauczycieli na istniejące zagrożenia, a tym samym zmniejszanie poprzez szeroko pojętą debatę pojawiających się napięć czy uprzedzeń. Idzie o akceptację kulturowej odmienności tradycji w sąsiedzkiej wspólnocie przestrzeni. Nota bene egzemplifikowane w tomie przeprowadzone eksplikacje przyczyniają się do odtwarzania ogólnych reguł psychospołecznych towarzyszących konstruowaniu wyobrażeń pojawiających się w danej narodowości na rzecz uproszczonej i emocjonalnie zabarwionej wizji mniejszej każdej przecież grupy etnicznej.

Książka z pewnością stymuluje Czytelników do rewizji zastanych stereotypów i ich historycznie sprawczej roli w występowaniu mitów, animozji napięć czy raportów, a obecnie kolejnych nowych bądź starych wznowionych publicznie uproszczeń. Powstają one z racji intensywnej ruchliwości przestrzennej (migracja międzynarodowa z perspektywy dynamiki procesów integracyjnych). Omówione fakty ściśle korelują z jakością oświaty i kształcenia, które od początku bieżącego stulecia pozostają przedmiotem inten- 
sywnych debat. Niestety, jak wiemy, niekoniecznie wprowadzonych reform czy chociażby zasadnych i oczekiwanych innowacji nie wspominając już o ich dyfuzji. Książka, o czym jestem bezgranicznie przekonany, odegra poważną rolę w praktyce publicznej, tak w sferze diagnozy, jak i metodologicznych, w wielu przypadkach oryginalnych rozwiązań.

Pomimo zróżnicowanego statusu naukowego poszczególnych autorów - tom winien sprostać wielu intelektualnym oczekiwaniom czytelniczym. Interesujący wydaje się przyjęty przez redaktorów naukowych podział treści i narracja treści. Czuję się zobligowany, ponieważ książka ukazała się drukiem w języku angielskim, do prezentacji tytułów poszczególnych rozdziałów w ich tłumaczeniu na język polski. Zaznaczam przy tym, iż w przeciwieństwie do naszego języka polskiego, język angielski posiada charakter idiomatyczny. Aby uzyskać trafność i rzetelność przykładu, w nawiasach starałem się uzupełnić nomenklaturę pojęciową w rodzime sformułowania, aby uwiarygodnić tym samym dokładność przykładu².

Struktura podziału treści (Spis treści) przedstawia się, jak następuje:

Tadeusz Lewowicki Wprowadzenie, s. 3

Ewa Ogrodzka-Mazur, Barbara Chojnacka-Synaszko \& Urszula Klajmon-Lech Społeczności polsko-czeskiego pogranicza w sytuacji zmian społecznych oraz kulturowych w latach 1990-2018 - charakterystyka środowiska i badanych grup, s. 14

Katarzyna Olbrycht Edukacyjne wymiary wspierania rozwoju duchowości czlowieka, s. 23

\section{Część I. PRZEMIANY WARTOŚCI I ASPIRACJI ŻYCIOWYCH}

Ewa Ogrodzka-Mazur Wartości cenione przez młode pokolenie Polaków i ich cele życiowe - zasoby indywidualne $i$ wspólnotowe w budowaniu kapitatu Pogranicza, s. 34.

Gabriela Piechaczek-Ogierman Aspiracje i plany edukacyjno-zawodowe w procesie kształtowania tożsamości młodzieży, s. 55.

Aleksandra Minczanowska Wybrane uwarunkowania samooceny uczniów w aspekcie ich rozwoju duchowego, s. 67.

2 Nadmieniam przy tym, iż władając językiem angielskim dla własnej użyteczności jego znajomości, nie jestem w stanie autorytatywnie doszukać się jakichkolwiek filologicznych uchybień. Można oczekiwać, że pierwszy recenzent/opiniodawca książki, Amerykanin prof. dr William New, z pewnością zwróciłby uwagę na poprawność/ niepoprawność dokonanego przekładu na jęz. angielski. 


\section{Część II. RELIGIA I TOLERANCJA RELIGIJNA}

Barbara Grabowska Postawy tolerancyjne młodzieży na pograniczu polsko-czeskim, s. 82.

Aniela Różańska Postrzeganie inności religijnej przez młodzież, s. 103.

Urszula Klajmon-Lech Młodzież pogranicza a wspólnota religijna, s. 118.

\section{Część III. ZACHOWANIA TOŻSAMOŚCIOWE I POSTAWY WOBEC INNYCH}

Łukasz Kwadrans Zachowania tożsamościowe młodzieży i tolerancja dla odmienności kulturowej, s. 132.

Barbara Chojnacka-Synaszko Pojmowanie roli języka $w$ ksztattowaniu tożsamości i w relacjach $z$ innymi poprzez przedstawicieli społeczności wielokulturowych, s. 147.

\section{Część IV. O NAUCZYCIELACH, ICH SPOSTRZEGANIU ŚWIATA SPO- LECZNEGO I AKTYWNOŚCI}

Anna Szafrańska Inny - daleki czy bliski. Wspótpraca z Czechami i obraz sasiadów z perspektywy polskich nauczycieli, s. 164.

Alina Szczurek-Boruta Dwie racjonalności w działaniach nauczycieli, s. 175.

\section{KONKLUZJE}

Tadeusz Lewowicki Przejawy stałości i zmienności w różnych obszarach życia duchowego - kilka uogólnień w tle teorii zachowań tożsamościowych, s. 186. Wykaz publikacji serii „Edukacja Międzykulturowa”, s. 201.

Noty o Autorach, s. 212.

Autorzy, a nade wszystko leader/wspótlider całej szkoły naukowej3, o czym wielokrotnie wspominałem w przeszłości, profesor Tadeusz Lewowicki, zarazem we Wstępie (Preface), jak i zakończeniu (Conclusions) nawiązuje do koncepcji uktadu odosobnionego, pojawiającego się w teorii Floriana Znanieckiego, dzisiaj często pomijanego nie tylko w pracach pedagogów, a doty-

3 Pozwalam sobie ponownie uzupełnić niniejszą informację, iż zdecydowana większość Autorów identyfikowana jest ze znaną w Europie szkołą naukową (międzyakademicki zespół) z zakresu edukacji, któremu przewodzą m.in. profesorowie: prof. dr hab. Tadeusz Lewowicki, Jerzy Nikitorowicz, Tadeusz Pilch, Zenon Jasiński, Ewa Ogrodzka-Mazur, Alina Szczurek-Boruta, Barbara Grabowska, Anna Szafrańska, Mirosław Sobecki i inni, których nazwisk nie wymieniam, którzy pomyślnie współkreują rozwój osiągnięć całej Szkoły Edukacji Międzykulturowej. 
czącego asymilacji zjawisk kulturowych szczególnego rodzaju. Jak pisał przed laty genialny uczony „[...] istnienie każdego zjawiska społecznego, i każdego zjawiska humanistycznego w ogóle, w świecie ludzkiego doświadczenia jest wynikiem działalności twórczej, a więc eo - ipso nie może być ujętym w prawa przyczynowe" (Znaniecki, 1943).

Aktywność podmiotów świadomych (m.in. nauczycieli), leżąca u podstaw zaistnienia, trwania i zmian wszelkich zjawisk kulturowych, przenosi na te zjawiska, jako swoje wytwory, swą dwoistą naturę. Każde zjawisko kulturowe zawiera dwa elementy: nowości i powtarzalności. Element nowości, oryginalności, niepowtarzalności zjawiska kulturowego związany jest z twórczym charakterem wytwarzającego i aktualizującego go działania. Działanie wnosi do wytworów takie cechy, których zaistnienie można wyjaśnić tylko poprzez odwołanie się do kształtu i przebiegu samego działania, nigdy zaś do warunków systemu kulturowego, w których działanie to było realizowane. Natomiast drugi element, tj. powtarzalność niektórych cech i aspektów zjawiska kulturowego, wynika z faktu, iż działalność podmiotu świadomego może dostosować się do warunków wytwarzanych przez nowy system kulturowy w trakcie jej przebiegu, tj. socjalizacji. Ten element zjawiska można wyjaśnić przyczynowo, poprzez odwołanie się do warunków, w jakich działanie przebiegało (Cichocki, 1989, s. 76-77).

Można zauważyć, że w każdym niemal artykule procesy socjalizacyjno-wychowawcze są szczególnie eksponowane. Świadomość wszystkich członków zespołu autorskiego nawiązuje do roli instytucji rodziny i szkoły dla procesów spoistości/integracji społecznej i narodowej. Powyższa praca wydaje się adresowana nade wszystko ku profesjonalnym reprezentantom nauk społecznych, nauczycielom i rodzicom oraz politykom społecznym. Dodam, że wieloaspektowa i wnikliwa interpretacja wielu zjawisk odnotowanych w badaniach sugeruje, iż po tę pracę winni sięgnąć wszyscy zainteresowani współczesną wieloaspektową rzeczywistością społeczną współczesnej Unii Europejskiej, śledząc wielostronny i przeanalizowany w tej książce materiał badawczy na przykładzie eksplorowanego pogranicza polsko-czeskiego.

Andrzej Radziewicz-Winnicki 